\title{
Shelf Life Extension of Veal Meat by Edible Coating Incorporated with Zataria multiflora Essential Oil
}

\author{
Hannan Lashkari $\mathbb{D}^{1},{ }^{1}$ Majid Halabinejad, ${ }^{2}$ Alireza Rafati, ${ }^{2}$ and Ameneh Namdar ${ }^{3}$ \\ ${ }^{1}$ Department of Food Science and Technology, Zarin Dasht Branch, Islamic Azad University, Zarin Dasht, Iran \\ ${ }^{2}$ Food Science and Technology Department, Sarvestan Branch, Islamic Azad University, Sarvestan, Iran \\ ${ }^{3}$ Department of Mathematics, Zarin Dasht Branch, Islamic Azad University, Zarin Dasht, Iran
}

Correspondence should be addressed to Hannan Lashkari; hlashkari@gmail.com

Received 14 June 2020; Revised 30 July 2020; Accepted 17 August 2020; Published 28 August 2020

Academic Editor: Hadi Hashemi Gahruie

Copyright ( 92020 Hannan Lashkari et al. This is an open access article distributed under the Creative Commons Attribution License, which permits unrestricted use, distribution, and reproduction in any medium, provided the original work is properly cited.

\begin{abstract}
The present research aimed to investigate the preservative effects of a sodium caseinate (SC) coating enriched with Zataria multiflora Boiss. essential oil (ZMEO) at $0.5,1$, or $1.5 \%$ on the product life of meat during storage at $4^{\circ} \mathrm{C}$. Over a 15 -day period, the meat samples were refrigerated and analyzed every five days. The treated samples had markedly less psychrotrophic bacteria, lactic acid bacteria, Enterobacteriaceae, and total viable counts relative to the control throughout storage. In terms of the sensory, chemical (PV, TBARS, and $\mathrm{pH}$ ), and microbial characterization, undesirable results were attained in the control sample after 10 days of refrigerated storage, whereas samples coated with SC/ZMEO, especially at higher essential oil concentrations (1 and $1.5 \%)$, proved to be significantly more stable $(P<0.05)$. However, high concentration of ZMEO $(1.5 \%)$ gave an unpleasant effect on sensory attributes of meat samples. Notably, the SC/1\% ZMEO coating led to good overall acceptability of the veal specimens even after 15 days of refrigeration. Hence, this coating is recommended as a replacement for synthetic preservatives and flavorings for meat products given that it preserved the quality of refrigerated veal samples for over two weeks.
\end{abstract}

\section{Introduction}

High moisture and nutrient levels make veal meat highly susceptible to microbial spoilage, with aerobic conditions facilitating lipid and protein oxidation. The quality of stored meat can be improved if measures are taken to avert such processes [1]. Numerous factors can influence microbial spoilage of meat and meat products. Later than slaughtering, meat can be contaminated with bacteria from various sources including washing water, air, and soil as well as human resources and the meat processing equipment [1].

Over the past few years, many researchers have attempted to prolong the shelf life of foods with a wide range of methods, among which the use of films and coatings prepared from natural products seems highly promising given the health-related problems of synthesized preservatives and the deteriorative effects of thermal [2-4]. Various organic substances such as carbohydrates, lipids, and proteins can be used to develop edible films and coatings [5]. Among these substances, polysaccharides are highly regarded for such applications due to possessing appropriate film-forming characteristics.

Consumers are highly interested in the incorporation of essential oils into food products given the benefits of such natural additives. Zataria multiflora Boiss., which grows in Iran, Pakistan, and Afghanistan [6-8], has antiseptic, analgesic, and carminative properties [9]. Due to containing a large amount of phenolic oxygenated monoterpenes (e.g., menthol and carvone), Z. multiflora essential oil (ZMEO) possesses potent activity against both microbes and oxidants $[10,11]$. A novel research issue that is yet to be explored is the supplementation of sodium caseinate-based films with ZMEO and the evaluation of the related applications in the packaging of real foods (e.g., veal meat). Hence, the current study aimed to examine caseinate coatings supplemented with ZMEO in terms of their effects on the chemical, microbiological, and sensorial properties of veal stored for a period of 15 days at $4^{\circ} \mathrm{C}$. 


\section{Materials and Methods}

2.1. Extraction of the Essential Oil. The Z. multiflora Boiss. plant was obtained locally in Shiraz, Iran $(30.060 \mathrm{~N}$, $52.560 \mathrm{E}$ ). To extract the ZMEO, we followed the technique of Moosavi-Nasab et al. [12]. In brief, the aerial segments of Z. multiflora were dried and then placed in a Clevenger type (Jal Tajhiz, Iran) apparatus for $3 \mathrm{~h}$ to allow hydrodistillation. The distilled ZMEO was dried over anhydrous sodium sulphate (Merck Co., Germany). Ahead of experimentation, the samples were sealed within dark vials and kept at a temperature of $-18^{\circ} \mathrm{C}$.

2.2. GC-FID Characterization. To determine the chemical composition of the ZMEO, a gas chromatograph device (Agilent 7890A) containing a flame ionization detector (FID) was used. The experimentation was done on a fused silica capillary HP-5 column $(30 \mathrm{~m}, 0.32 \mathrm{~mm}$ i.d.; film thickness $0.25 \mathrm{~mm}$ ) and $250^{\circ} \mathrm{C}$ and $280^{\circ} \mathrm{C}$ were used as the injector and detector temperatures, respectively. The carrier gas used was nitrogen, with a flow rate of $1 \mathrm{~mL} / \mathrm{min}$ being employed; the temperature of the oven was boosted at a constant rate of $4^{\circ} \mathrm{C}$ per minute from 60 to $210^{\circ} \mathrm{C}$, before being augmented to a final temperature of $240^{\circ} \mathrm{C}$ at a rate of $20^{\circ} \mathrm{C}$ per minute. The final temperature was maintained for $8.5 \mathrm{~min}$. A split ratio of 1:50 was used.

2.3. Preparation of Coating Solutions. To prepare the coating solutions, $50 \mathrm{~g}$ of sodium caseinate (Merck Co., Germany) was gradually added under constant stirring at $550 \mathrm{rpm}$ to a solution (at $60-65^{\circ} \mathrm{C}$ ) composed of $1 \mathrm{~L}$ of distilled water and $15 \mathrm{~g}$ of glycerol (Merck Co., Germany). Stirring and heating of the mixture took place for an hour using a heater stirrer (IKA ${ }^{\circledR}$ RCT basic, Staufen, Germany) set at $80 \pm 3^{\circ} \mathrm{C}$ in an effort to enhance the mechanical properties of films by establishing disulphide bounds in casein structure. To eliminate any undissolved particles, the solution was then passed through Whatman filter paper (No. 3). The prepared solution was then distributed equally across four different groups. Subsequently, the ZMEO $(0.5,1$, or $1.5 \% \mathrm{v} / \mathrm{v})$ was incorporated into three of the prepared film solutions, with the fourth solution containing only sodium caseinate. The immersion technique was used to coat the meat samples. To remove excess biopolymer solution from coated samples, they were allowed for around 10 minutes at ambient temperature. Storage of the veal occurred over a period of 15 days at $4^{\circ} \mathrm{C}$, with experimentations being performed every five days.

2.4. Chemical Characterization. To obtain meat quality over the storage, the $\mathrm{pH}$ variations were evaluated using the technique presented by Moosavi-Nasab et al. [12]. Briefly, meat specimens $(10 \mathrm{~g})$ were homogenized for five $\mathrm{min}$ in a stomacher blender (Jal Tajhiz, Iran) with 10 volumes of deionized water. Then, the electrode of a Suntex TS-1 pHmeter (Taiwan) was directly immersed into the sample to evaluate the $\mathrm{pH}$. Peroxide values were evaluated following the technique of Shahamirian et al. [13]; the results were reported as the $\mathrm{mmol}$ of $\mathrm{O}_{2}$ per $\mathrm{kg}$ of the veal. To evaluate the extent of lipid oxidation, the thiobarbituric acid reactive substance (TBARS) values were determined and reported in terms of the milligrams of malondialdehyde (MDA) per kilogram of the veal. In this procedure, a mixture of veal specimens and trichloroacetic acid (Merck Co, Germany) was centrifuged before the filtrate was vortexed together with thiobarbituric acid. After homogenization, the resulting samples were incubated for $20 \mathrm{~min}$ within a water bath set at $97^{\circ} \mathrm{C}$. Finally, absorbance was evaluated at a wavelength of $532 \mathrm{~nm}$. The calibration curve was prepared using a precursor of MDA called 1,1,3,3-tetramethoxypropane (99\%). To convert the final results related to $1 \mathrm{M}$ of 1,1,3,3-tetramethoxypropane equivalent per gram of the veal specimens, the values were multiplied by the MDA's molecular weight.

2.5. Microbiological Analysis. The microbiological population of meat samples over the storage was analyzed using the technique described by Moosavi-Nasab et al. [12]. First, a Stomacher blender was used to mix $10 \mathrm{~g}$ veal samples with $90 \mathrm{ml}$ of saline solution (as the diluent). Subsequently, two further dilutions were made and $1 \mathrm{~mL}$ samples were added to the culture media $15 \mathrm{~mL}$ situated within Petri dishes. The bacterial counts were made in duplicate and were reported in terms of log CFU per gram. The culture media (all supplied by Merck Co.) and incubation conditions varied for the different investigations. Plate count agar was used for the psychrotrophic bacteria and total viable counts, while the Enterobacteriaceae and lactic acid bacteria were enumerated after growth on violet red bile agar and MRS agar, respectively. The incubation duration and temperature prior to each of the four counts in the order mentioned were 10 days at $4 \pm 2^{\circ} \mathrm{C}$, two days at $37 \pm 2^{\circ} \mathrm{C}$, one day at $37 \pm 2^{\circ} \mathrm{C}$, and two to three days at $37 \pm 2^{\circ} \mathrm{C}$, respectively.

2.6. Sensory Characterization. To assess the veal samples in terms of changes in organoleptic characteristics during storage, ten panelists who were trained for such experimentations were recruited. The panel was blind to the nature of each sample. Each panelist was asked to score the samples from one (dislike extremely) to nine (like extremely) on a hedonic scale in terms of texture, odor, color, and overall acceptability. Sample acceptability was defined as a mean sensory score of five or above [3].

2.7. Color Variables and Visual Scores. Color variables of meat samples were evaluated at 1, 5, 10, and 15 days according to the procedure of Hosseini et al. [14]. For each sample, the $\mathrm{L}^{*}$ (brightness), $\mathrm{a}^{*}$ (red-green nature), and $b^{*}$ (yellow-blue nature) measurements were made using Adobe Photoshop ${ }^{\circledR}$ CS6 at six different points that were selected at random from the entire surface of the veal samples. The photos were taken using a Canon PowerShot A540 (resolution: six megapixels) within a wooden box $\left(50 \times 50 \times 60 \mathrm{~cm}^{3}\right)$ under natural daylight $(6500 \mathrm{~K})[14]$. 
2.8. Statistical Analysis. The experimentation was done in triplicate. Significant differences between means were determined using the SAS 9.1 program (SAS Inc., USA) at a significance level of 0.05 ; the tests used were Duncan's test and one-way analysis of variance (ANOVA) [15].

\section{Results and Discussion}

3.1. Chemical Composition of ZMEO. A $1.19 \%$ extraction efficiency was achieved for ZMEO. The composition of this essential oil is summarized in Table 1. Through the GC/FID study, a total of 14 different components (98.49\%) were identified in the ZMEO, with carvacrol (42.22\%) and thymol $(26.93 \%)$ being the chief constituents. These findings are in agreement with those of Ziaee et al. [15], who used the same technique and identified 14 components of ZMEO, among which carvacrol (39.29\%) and thymol (25.24\%) were the chief components. Furthermore, Moradi et al. [16] stated that the content of ZMEO in the aerial portion of $Z$. multiflora Boiss. was approximately $1.2 \% \mathrm{v} / \mathrm{w}$, with carvacrol (41.2\%) and thymol (27.4\%) again being the major components. Other results show that the proportion of the components of ZMEO varies according to the origin of the $Z$. multiflora Boiss. plant, although the chief components of this essential oil are monoterpene hydrocarbons, oxygenated monoterpenes, thymol, and carvacrol.

3.2. Chemical Analysis. Table 2 summarizes the chemical properties of the veal specimens during refrigeration $\left(4^{\circ} \mathrm{C}\right)$ for 15 days. The initial $\mathrm{pH}$ values of coated meat samples with sodium caseinate (control) and sodium caseinate incorporated with $0.5,1$, and $1.5 \%$ ZMEO were 5.50, 5.39, 5.38, and 5.28, respectively. These results are in line with those of a different study [17]. However, different species, diet, season, and stress level before and during slaughtering can lead to different $\mathrm{pH}$ values among meats. The $\mathrm{pH}$ differences among meat samples can be derived from coating solutions $\mathrm{pH}$ and higher concentration of ZMEO. All meat samples experienced considerable rises in $\mathrm{pH}$ values during storage. In the control sample, this could be explained by the activity of enzymes (e.g., protease and lipase) present in the meat and/ or microbes, which leads to an increased concentration of volatile bases like ammonia and trimethylamine [18]. Generally, the veal specimens coated with the sodium caseinate/ZMEO coatings maintained lower $\mathrm{pH}$ values compared with the control. This could be explained by the antimicrobial activity of the ZMEO given the strong presence of constituents like thymol and carvacrol.

The primary oxidation products were measured by peroxide valued index. Meat products possess high susceptibility to both microbial spoilage and chemical deterioration [19]. Table 2 summarizes the impact of the coatings on the alteration of the PV in the veal samples. While all samples (control/treatments) experienced significant increments in PVs during storage $(P<0.05)$, the samples coated with sodium caseinate/ZNEO had significantly lower PVs $(P<0.05)$ than the control on day 15 . Hence, the treatments were able to impede the process of peroxidation in veal during refrigerated storage. Sharififar et al. [20] found ZMEO to effectively inhibit the oxidation of linoleic acid and proposed this to be the result of the free radical scavenging activity of the phenolic compounds present in ZMEO. In our study, the samples coated with sodium caseinate alone showed the highest PV values, which reached 7.82 on day 15 . Significantly lower PV values were obtained for treated samples, especially for those coated with higher ZMEO concentration. Table 2 summarizes the findings related to the TBARS analyses for veal specimens stored at $4^{\circ} \mathrm{C}$. The lipid oxidation of all meat samples was initially low (below $0.5 \mathrm{mg} \mathrm{MDA} / \mathrm{kg}$ ). In general, the TBARS values gradually increased until the tenth day of storage, after which they fell until the closure of the experimentation (day 15). A similar trend has been reported by Chouliara et al. [21] in regard to chicken breasts. These results are explained by the production of MDA during the early days of storage ahead of its breakdown, which occurred toward the end of the experimentation. It should be noted, however, that, relative to the control sample, the MDA values of the veal fell significantly $(P<0.05)$ with the addition of different ZMEO concentrations $(0.5,1$, or $1.5 \%)$. The vast amounts of phenolic components in ZMEO give rise to excellent antioxidant characteristics. These findings are in line with those reported in the literature $[1,22]$. Furthermore, we found that the sodium caseinate coating significantly promoted the activity of ZMEO (1 or 1.5\%) against lipid oxidation, which can perhaps be ascribed to the protective impact of sodium caseinate on the phenolic compounds of ZMEO [23].

3.3. Microbiological Analysis. Table 3 summarizes the microbiological parameters of meat samples coated with sodium caseinate with and without different concentrations of ZMEO during 15 days of refrigerated $\left(4^{\circ} \mathrm{C}\right)$ storage. The initial total plate count (TPC) of control and control plus 0.5 , 1 , and 1.5\% ZMEO meat samples was 4.16, 4.22, 3.88, and $3.22 \log \mathrm{CFU} / \mathrm{g}$, respectively. In line with the results of similar studies, the TPC progressively increased in the control sample [12, 24-26]. After 10 days, the TPC of the control sample and control plus 0.5\% ZMEO passed the suggested limit for raw meat ( 7 log CFU/g), reaching 7.64 and $7.42 \log$ CFU/g, respectively [27]. However, the TPCs of veal specimens coated with sodium caseinate and $1-1.5 \%$ ZMEO stayed under $6 \log \mathrm{CFU} / g$ throughout the 15 days of storage. A number of researchers have stated that the utilization of coatings enriched with antimicrobial agents can prolong fresh quality of meat and meat products $[12,17,27]$.

Table 3 also outlines the alterations in the PBC of the veal samples during the storage time. The initial count for control and control plus $0.5,1$, and $1.5 \% \mathrm{ZMEO}$ was $2.34,2.4,2.01$, and $1.68 \log \mathrm{CFU} / \mathrm{g}$, respectively. During storage, meat samples coated by sodium caseinate plus $1.5 \%$ ZMEO had the minimum PBC. After the 15-day storage period had come to an end, the PBC of the control and control plus 0.5, 1 , and $1.5 \%$ ZMEO coated samples was 6.6, 5.8, 3.8, and 2.5 $\log \mathrm{CFU} / \mathrm{g}$, respectively. Hence, ZMEO had a remarkable effect against the psychrophilic bacteria present in refrigerated meat samples. 
TABLE 1: Chemical compositions of essential oil obtained by hydrodistillation from Zataria multiflora using GC/FID.

\begin{tabular}{lcccc}
\hline No & Compound & Retention index & Retention time (min) & Relative peak area (\%) \\
\hline 1 & $\alpha$-Thujene & 924 & 1.533 & 0.1532 \\
2 & $\alpha$-Pinene & 932 & 4.232 & 3.933 \\
3 & 3 -Octanone & 984 & 5.620 & 3.203 \\
4 & Myrcene & 988 & 6.527 & 1.202 \\
5 & $\alpha$-Terpinene & 1014 & 6.849 & 10.87 \\
6 & p-Cymene & 1020 & 7.931 & 2.239 \\
7 & $\gamma$-Terpinene & 1054 & 13.060 & 0.4015 \\
8 & Linalool & 1095 & 15.422 & 0.5058 \\
9 & Carvacrol methyl ether & 1241 & 17.863 & 0.9719 \\
10 & Thymol & $\mathbf{1 2 8 9}$ & $\mathbf{1 8 . 3 6 3}$ & $\mathbf{2 6 . 9 3}$ \\
11 & Carvacrol & $\mathbf{1 2 9 8}$ & $\mathbf{1 8 . 7 7 6}$ & $\mathbf{4 2 . 2 2}$ \\
12 & Eugenol & 1361 & 23.088 & 2.268 \\
13 & Carvacrol acetate & 1370 & 29.882 & 4.346 \\
14 & $\beta$-Caryophyllene & 1417 & 40.757 & 2.253 \\
\hline
\end{tabular}

Entries in bold are the main components of Zataria multiflora essential oil.

TABLE 2: Changes in chemical properties of SC and SC + ZMEO coated meat samples during 15 days' storage at refrigerated temperatures ${ }^{\mathrm{a}}$.

\begin{tabular}{|c|c|c|c|c|c|}
\hline & & \multicolumn{4}{|c|}{ Storage days at $4^{\circ} \mathrm{C}$} \\
\hline & & 1 & 5 & 10 & 15 \\
\hline \multirow{4}{*}{$\mathrm{pH}$} & SC & $5.50 \pm 0.01^{\mathrm{Da}}$ & $5.92 \pm 0.02^{\mathrm{Ca}}$ & $6.47 \pm 0.03^{\mathrm{Ba}}$ & $7.82 \pm 0.04^{\mathrm{Aa}}$ \\
\hline & $\mathrm{SC}+0.5 \% \mathrm{ZMEO}$ & $5.45 \pm 0.04^{\mathrm{Da}}$ & $5.82 \pm 0.04^{\mathrm{Ca}}$ & $6.58 \pm 0.03^{\mathrm{Ba}}$ & $7.42 \pm 0.07^{\mathrm{Ab}}$ \\
\hline & $\mathrm{SC}+1 \% \mathrm{ZMEO}$ & $5.38 \pm 0.06^{\mathrm{Da}}$ & $5.65 \pm 0.03^{\mathrm{Cb}}$ & $5.91 \pm 0.07^{\mathrm{Bb}}$ & $6.32 \pm 0.07^{\mathrm{Ac}}$ \\
\hline & $\mathrm{SC}+1.5 \% \mathrm{ZMEO}$ & $5.38 \pm 0.11^{\mathrm{Ca}}$ & $5.33 \pm 0.04^{\mathrm{Cc}}$ & $5.69 \pm 0.02^{\mathrm{Bc}}$ & $5.89 \pm 0.05^{\mathrm{Ad}}$ \\
\hline \multirow{4}{*}{ PV } & SC & $1.38 \pm 0.07^{\mathrm{Da}}$ & $3.78 \pm 0.11^{\mathrm{Ca}}$ & $5.94 \pm 0.07^{\mathrm{Ba}}$ & $7.82 \pm 0.05^{\mathrm{Aa}}$ \\
\hline & $\mathrm{SC}+0.5 \% \mathrm{ZMEO}$ & $1.45 \pm 0.08^{\mathrm{Da}}$ & $3.11 \pm 0.09^{\mathrm{Cb}}$ & $3.98 \pm 0.06^{\mathrm{Bb}}$ & $5.66 \pm 0.04^{\mathrm{Ab}}$ \\
\hline & $\mathrm{SC}+1 \% \mathrm{ZMEO}$ & $1.28 \pm 0.06^{\mathrm{Da}}$ & $2.61 \pm 0.13^{\mathrm{Cc}}$ & $3.36 \pm 0.05^{\mathrm{Bc}}$ & $4.21 \pm 0.05^{\mathrm{Ac}}$ \\
\hline & $\mathrm{SC}+1.5 \% \mathrm{ZMEO}$ & $1.33 \pm 0.9^{\mathrm{Da}}$ & $1.87 \pm 0.08^{\mathrm{Cd}}$ & $2.06 \pm 0.04^{\mathrm{Bd}}$ & $2.67 \pm 0.05^{\mathrm{Ad}}$ \\
\hline \multirow{4}{*}{ TBARS } & SC & $0.28 \pm 0.12^{\mathrm{Ca}}$ & $0.49 \pm 0.08^{\mathrm{Ca}}$ & $1.29 \pm 0.07^{\mathrm{Aa}}$ & $1.08 \pm 0.04^{\mathrm{Ba}}$ \\
\hline & $\mathrm{SC}+0.5 \% \mathrm{ZMEO}$ & $0.31 \pm 0.11^{\mathrm{Ca}}$ & $0.43 \pm 0.04^{\mathrm{Ca}}$ & $1.12 \pm 0.08^{\mathrm{Ab}}$ & $0.88 \pm 0.05^{\mathrm{Bb}}$ \\
\hline & $\mathrm{SC}+1 \% \mathrm{ZMEO}$ & $0.27 \pm 0.14^{\mathrm{Ca}}$ & $0.33 \pm 0.06^{\mathrm{Cb}}$ & $0.86 \pm 0.02^{\mathrm{Ac}}$ & $0.71 \pm 0.09^{\mathrm{Bc}}$ \\
\hline & $\mathrm{SC}+1.5 \% \mathrm{ZMEO}$ & $0.31 \pm 0.12^{\mathrm{Ba}}$ & $0.33 \pm 0.08^{\mathrm{Bb}}$ & $0.62 \pm 0.07^{\mathrm{Ad}}$ & $0.51 \pm 0.04^{\mathrm{Ad}}$ \\
\hline
\end{tabular}

SC, sodium caseinate; ZMEO; Zataria multiflora essential oil. Data represent the mean value of three replicates \pm SD. Means within each row with different uppercase letters are significantly different $(P<0.05)$, and means within each column with different lowercase letters are significantly different $(P<0.05)$.

Meat spoilage is mostly the result of the activity of lactic acid bacteria (LAB), with certain species (Lactobacillus spp., Carnobacterium spp., and Leuconostoc spp.) being more involved in this process [28]. In our study, the initial LAB counts of control and control plus 0.5, 1, and 1.5\% ZMEO coating in meat samples were $1.28,1.33,1.28$, and $1.16 \log$ $\mathrm{CFU} / \mathrm{g}$, respectively. The minimum $\mathrm{LAB}$ counts were found in the veal samples that had the sodium caseinate $+1.5 \%$ ZMEO coating, amounting to 1.16 and $2.88 \mathrm{log} \mathrm{CFU} / \mathrm{g}$ on days 1 and 15, respectively. The LAB count was significantly different between the various samples $(P<0.05)$, though a progressive rise in the number of $\mathrm{LAB}$ was generally apparent. On day 15, the LAB counts of control and control plus $0.5,1$, and $1.5 \%$ ZMEO coated samples increased to levels of $5.22,4.6,3.84$, and $2.88 \log \mathrm{CFU} / \mathrm{g}$, respectively. It should be noted that, among the various types of Grampositive bacteria, $\mathrm{LAB}$ reportedly possess the maximum resistance against essential oils [29]. According to our results, LAB growth was markedly stunted in specimens coated with sodium caseinate and elevated concentrations of ZMEO, which could be related to the presence of phenolic compounds in the essential oil. Frangos et al. [30] proposed that such antimicrobial resistance of LAB is a result of the ability of these species to deal with both the osmotic stress and the efflux of potassium ions induced by the essential oils. In another research, Khorsandi et al. (2018) examined 5 different essential oils against LAB causing spoilage in vacuum packed curd sausage. They reported that EOs have antimicrobial activity against LAB and their activity depended on their main components. The minimum growth of $L A B$ was seen in the veal specimen coated with sodium caseinate $1.5 \%$ ZMEO, confirming the favorable antimicrobial properties of ZMEO [31].

Table 3 also depicts the results related to Enterobacteriaceae, for which the initial counts of control and control plus $0.5,1$, and $1.5 \%$ ZMEO coating were $3.12,3.22$, 3.08 , and $2.96 \log \mathrm{CFU} / \mathrm{g}$, respectively. At the end of storage, the control specimen had an Enterobacteriaceae count of 7.8 $\log \mathrm{CFU} / \mathrm{g}$. However, meat specimens coated with sodium caseinate incorporated with 1 and $1.5 \%$ ZMEO had 2 and 3.3 $\log \mathrm{CFU} / \mathrm{g}$ less counts than the control, respectively (Table 3). This could be explained by the activity of ZMEO against such spoilage bacteria, which has also been described by other researchers $[4,15,16]$. The meat sample coated with 
TABLE 3: Changes in microbial counts of SC and SC + ZMEO coated meat samples during 15 days of storage at refrigerated temperatures ${ }^{\mathrm{a}}$.

\begin{tabular}{|c|c|c|c|c|c|}
\hline & & \multicolumn{4}{|c|}{ Storage days at $4^{\circ} \mathrm{C}$} \\
\hline & & 1 & 5 & 10 & 15 \\
\hline \multirow{4}{*}{ APC } & $\mathrm{SC}$ & $4.16 \pm 0.11^{\mathrm{Da}}$ & $5.11 \pm 0.16^{\mathrm{Ca}}$ & $7.64 \pm 0.32^{\mathrm{Ba}}$ & $8.35 \pm 0.08^{\mathrm{Aa}}$ \\
\hline & $\mathrm{SC}+0.5 \% \mathrm{ZMEO}$ & $4.22 \pm 0.08^{\mathrm{Da}}$ & $5.33 \pm 0.12^{\mathrm{Ca}}$ & $7.42 \pm 0.08^{\mathrm{Ba}}$ & $8.21 \pm 0.12^{\mathrm{Aa}}$ \\
\hline & $\mathrm{SC}+1 \% \mathrm{ZMEO}$ & $3.88 \pm 0.06^{\mathrm{Db}}$ & $4.22 \pm 0.22^{\mathrm{Cb}}$ & $4.82 \pm 0.14^{\mathrm{Bb}}$ & $5.54 \pm 0.07^{\mathrm{Ab}}$ \\
\hline & $\mathrm{SC}+1.5 \% \mathrm{ZMEO}$ & $3.22 \pm 0.12^{\mathrm{Dc}}$ & $3.36 \pm 0.08^{\mathrm{Cc}}$ & $3.88 \pm 0.11^{\mathrm{Bc}}$ & $4.42 \pm 0.21^{\mathrm{Ac}}$ \\
\hline \multirow{4}{*}{$\mathrm{PBC}$} & $\mathrm{SC}$ & $2.34 \pm 0.08^{\mathrm{Da}}$ & $3.82 \pm 0.15^{\mathrm{Ca}}$ & $4.9 \pm 0.12^{\mathrm{Ba}}$ & $6.6 \pm 0.09^{\mathrm{Aa}}$ \\
\hline & $\mathrm{SC}+0.5 \% \mathrm{ZMEO}$ & $2.4 \pm 0.12^{\mathrm{Da}}$ & $2.62 \pm 0.11^{\mathrm{Cb}}$ & $3.2 \pm 0.18^{\mathrm{Bb}}$ & $5.8 \pm 0.08^{\mathrm{Ab}}$ \\
\hline & $\mathrm{SC}+1 \% \mathrm{ZMEO}$ & $2.01 \pm 0.11^{\mathrm{Db}}$ & $2.45 \pm 0.14^{\mathrm{Cb}}$ & $3.3 \pm 0.12^{\mathrm{Bc}}$ & $3.8 \pm 0.12^{\mathrm{Ac}}$ \\
\hline & $\mathrm{SC}+1.5 \% \mathrm{ZMEO}$ & $1.68 \pm 0.06^{\mathrm{Cc}}$ & $1.99 \pm 0.09^{\mathrm{Bc}}$ & $2.2 \pm 0.11^{\mathrm{Bd}}$ & $2.5 \pm 0.06^{\mathrm{Ad}}$ \\
\hline \multirow{4}{*}{ LAB } & SC & $1.28 \pm 0.12^{\mathrm{Da}}$ & $2.67 \pm 0.12^{\mathrm{Ca}}$ & $4.22 \pm 0.15^{\mathrm{Ba}}$ & $5.22 \pm 0.09^{\mathrm{Aa}}$ \\
\hline & $\mathrm{SC}+0.5 \% \mathrm{ZMEO}$ & $1.33 \pm 0.08^{\mathrm{Da}}$ & $2.43 \pm 0.17^{\mathrm{Ca}}$ & $3.8 \pm 0.13^{\mathrm{Bb}}$ & $4.6 \pm 0.12^{\mathrm{Ab}}$ \\
\hline & $\mathrm{SC}+1 \% \mathrm{ZMEO}$ & $1.28 \pm 0.08^{\mathrm{Da}}$ & $2.02 \pm 0.19^{\mathrm{Cb}}$ & $2.92 \pm 0.14^{\mathrm{Bc}}$ & $3.84 \pm 0.16^{\mathrm{Ac}}$ \\
\hline & $\mathrm{SC}+1.5 \% \mathrm{ZMEO}$ & $1.26 \pm 0.15^{\mathrm{Da}}$ & $1.88 \pm 0.12^{\mathrm{Bb}}$ & $2.12 \pm 0.11^{\mathrm{Bd}}$ & $2.88 \pm 0.15^{\mathrm{Ad}}$ \\
\hline \multirow{4}{*}{$\mathrm{EBC}$} & SC & $3.12 \pm 0.06^{\mathrm{Da}}$ & $4.62 \pm 0.11^{\mathrm{Ca}}$ & $6.8 \pm 0.12^{\mathrm{Ba}}$ & $7.8 \pm 0.22^{\mathrm{Aa}}$ \\
\hline & $\mathrm{SC}+0.5 \% \mathrm{ZMEO}$ & $3.22 \pm 0.09^{\mathrm{Da}}$ & $4.5 \pm 0.10^{\mathrm{Ca}}$ & $7.1 \pm 0.17^{\mathrm{Ba}}$ & $7.5 \pm 0.14^{\mathrm{Aa}}$ \\
\hline & $\mathrm{SC}+1 \% \mathrm{ZMEO}$ & $3.18 \pm 0.13^{\mathrm{Da}}$ & $3.88 \pm 0.05^{\mathrm{Cb}}$ & $5.2 \pm 0.15^{\mathrm{Bb}}$ & $5.8 \pm 0.12^{\mathrm{Ab}}$ \\
\hline & $\mathrm{SC}+1.5 \% \mathrm{ZMEO}$ & $2.96 \pm 0.12^{\mathrm{Da}}$ & $3.12 \pm 0.14^{\mathrm{Cc}}$ & $3.9 \pm 0.19^{\mathrm{Bc}}$ & $4.5 \pm 0.18^{\mathrm{Ac}}$ \\
\hline
\end{tabular}

SC, sodium caseinate; ZMEO, Zataria multiflora essential oil; TPC, total plate count; PBC, psychrotrophic bacterial count; LAB, lactic acid bacteria; EBC, Enterobacteriaceae counts. Data represent the mean value of three replicates \pm SD. Means within each row with different uppercase letters are significantly different $(P<0.05)$, and means within each column with different lowercase letters are significantly different $(P<0.05)$.

sodium caseinate plus $1.5 \% \mathrm{ZMEO}$ had the minimum count, highlighting the potent activity of ZMEO against the bacteria. Ziaee et al. [15] examined the mechanisms by which ZMEO exerts its antibacterial activity against $L$. curvatus. They reported that carvacrol and thymol, as the chief constituents of ZMEO, were the main antibacterial agents. Moreover, other researchers have also reported that these two compounds are mostly responsible for both the antibacterial and antioxidant activity of ZMEO [32-36]. Despite the fact that the bacterial counts for all veal specimens increased over time, the rate of this increment was significantly lower $(P<0.05)$ among the samples coated with SC/ZMEO relative to the control.

3.4. Color Variables. Table 4 shows the results related to the color parameters of the veal specimens during storage. Meat samples coated with sodium caseinate and sodium caseinate incorporated with $0.5 \% \mathrm{ZMEO}$ after 10 days were sticky due to spoilage, meaning that the color analysis was probably inaccurate; data related to those samples are hence not shown.

Coating materials can change consumer acceptability of food, since optical properties of an edible coating depending on the material type and concentration can change the overall appearance of food. Furthermore, myoglobin is a protein that mostly determines the color of meat; this protein takes the form of deoxymyoglobin or oxymyoglobin depending on the availability of oxygen, thereby influencing consumer acceptance [37]. Hence, color evaluation of a meat product during its shelf life is essential. Table 4 summarizes the color variables $\left(L^{*}, a^{*}\right.$, and $b^{*}$ ) during the refrigerated storage for all treatments. The $\mathrm{L}^{*}$, or lightness values, showed a decreasing rate over the storage for all specimens. The control had the minimum $L^{*}$ value after ten days of storage, probably due to alterations in meat color secondary to protein conformational changes that occurred due to oxidizing reactions and microbial growth [38]. In this regard, Soladoye et al. [39] reported that cross-linking between proteins and the carbonylation of protein molecules are related to decreases in muscle protein function and changes in the sensory characteristics of meat products. Over the 15-day period, the control sample underwent a significant decrease $(P<0.05)$ in terms of its $\mathrm{a}^{*}$ or redness value; this color loss was significantly less in the coated samples $(P<0.05)$. In fact, at the end of the storage period, the coated samples had $\mathrm{a}^{*}$ values higher than 10 , representing a bright red color [40]. A similar trend was seen in the $b^{*}$ values, with the drop in this parameter being more pronounced in the control sample $(P<0.05)$. Again, the coated samples had the maximum $b^{*}$ values, though this was probably because of the yellowish color of the coating and ZMEO.

3.5. Sensory Analysis. In order to attain the desired antioxidative and antimicrobial performance, elevated concentrations of essential oils are required. However, this gives rise to concerns regarding the effects of such oils on the sensory attributes of food products; this is particularly important for the essential oils of plants such as oregano and Z. multiflora Boiss., which exert strong flavors and odors [3]. Table 5 summarizes the sensory scores related to the color, texture, odor, and overall acceptability of the veal samples, with a general decrease over time being apparent. During the initial part of the storage time, the introduction of elevated ZMEO concentrations resulted in decreased odor scores. The samples coated with sodium caseinate and $0.5 \%$ and $1 \%$ ZMEO achieved the maximum sensory scores during the study time. Due to unsuitable organoleptic characteristics, the taste and 
TABLE 4: Changes in color variables of SC and SC + ZMEO coated meat samples during 15 days of storage at refrigerated temperatures ${ }^{\mathrm{a}}$.

\begin{tabular}{|c|c|c|c|c|c|}
\hline & & \multicolumn{4}{|c|}{ Storage days at $4^{\circ} \mathrm{C}$} \\
\hline & & 1 & 5 & 10 & 15 \\
\hline \multirow{4}{*}{$\mathrm{L}^{*}$} & $\mathrm{SC}$ & $41.08 \pm 0.43^{\mathrm{Aa}}$ & $38.95 \pm 0.16^{\mathrm{Ba}}$ & $31.25 \pm 0.33^{\mathrm{Cc}}$ & - \\
\hline & $\mathrm{SC}+0.5 \% \mathrm{ZMEO}$ & $40.56 \pm 0.26^{\mathrm{Aa}}$ & $38.12 \pm 1.08^{\mathrm{Bab}}$ & $33.42 \pm 0.27^{\mathrm{Cb}}$ & - \\
\hline & $\mathrm{SC}+1 \% \mathrm{ZMEO}$ & $37.54 \pm 018^{\mathrm{Ab}}$ & $37.95 \pm 0.23^{\mathrm{Bbc}}$ & $36.05 \pm 0.41^{\mathrm{Ca}}$ & $35.11 \pm 0.09^{\mathrm{Da}}$ \\
\hline & $\mathrm{SC}+1.5 \% \mathrm{ZMEO}$ & $36.06 \pm 0.38^{\mathrm{Ab}}$ & $35.95 \pm 0.13^{\mathrm{Ac}}$ & $34.28 \pm 0.37^{\mathrm{Bab}}$ & $33.11 \pm 0.12^{\mathrm{Cb}}$ \\
\hline \multirow{4}{*}{$a^{*}$} & $\mathrm{SC}$ & $12.54 \pm 0.11^{\mathrm{Ac}}$ & $10.11 \pm 0.14^{\mathrm{Bd}}$ & $7.92 \pm 0.22^{\mathrm{Cc}}$ & - \\
\hline & $\mathrm{SC}+0.5 \% \mathrm{ZMEO}$ & $12.45 \pm 0.08^{\mathrm{Ac}}$ & $11.09 \pm 0.11^{\mathrm{Bc}}$ & $7.65 \pm 0.22^{\mathrm{Cc}}$ & - \\
\hline & $\mathrm{SC}+1 \% \mathrm{ZMEO}$ & $13.87 \pm 0.18^{\mathrm{Ab}}$ & $13.93 \pm 0.09^{\mathrm{Ab}}$ & $12.26 \pm 0.28^{\mathrm{Bb}}$ & $13.11 \pm 0.08^{\mathrm{Ab}}$ \\
\hline & $\mathrm{SC}+1.5 \% \mathrm{ZMEO}$ & $15.11 \pm 0.22^{\mathrm{Aa}}$ & $15.45 \pm 0.21^{\mathrm{Aa}}$ & $15.87 \pm 0.08^{\mathrm{Aa}}$ & $15.33 \pm 0.09^{\mathrm{Aa}}$ \\
\hline \multirow{4}{*}{$b^{*}$} & SC & $15.19 \pm 0.17^{\mathrm{Ad}}$ & $13.23 \pm 0.32^{\mathrm{Bd}}$ & $11.41 \pm 0.19^{\mathrm{Cc}}$ & - \\
\hline & $\mathrm{SC}+0.5 \% \mathrm{ZMEO}$ & $16.76 \pm 0.21^{\mathrm{Ac}}$ & $14.76 \pm 0.14^{\mathrm{Bc}}$ & $11.09 \pm 0.06^{\mathrm{Cc}}$ & - \\
\hline & $\mathrm{SC}+1 \% \mathrm{ZMEO}$ & $17.33 \pm 0.35^{\mathrm{Ab}}$ & $17.45 \pm 0.08^{\mathrm{Ab}}$ & $16.11 \pm 0.08^{\mathrm{Bb}}$ & $17.09 \pm 0.04^{\mathrm{Ab}}$ \\
\hline & $\mathrm{SC}+1.5 \% \mathrm{ZMEO}$ & $19.05 \pm 0.19^{\mathrm{Aa}}$ & $18.98 \pm 0.17^{\mathrm{Aa}}$ & $19.27 \pm 0.11^{\mathrm{Aa}}$ & $19.08 \pm 0.13^{\mathrm{Aa}}$ \\
\hline
\end{tabular}

caseinate; ZMEO, Zataria multiflora essential oil. Data represent the mean value of three replicates \pm SD. Means within each row with diffe uppercase letters are significantly different $(P<0.05)$, and means within each column with different lowercase letters are significantly different $(P<0.05)$.

TABLE 5: Changes in sensorial properties of SC and SC + ZMEO coated meat samples during 15 days of storage at refrigerated temperatures ${ }^{\mathrm{a}}$.

\begin{tabular}{|c|c|c|c|c|c|}
\hline & & \multicolumn{4}{|c|}{ Storage days at $4^{\circ} \mathrm{C}$} \\
\hline & & 1 & 5 & 10 & 15 \\
\hline \multirow{4}{*}{ Color } & SC & $8.8 \pm 0.42^{\mathrm{Aa}}$ & $6 \pm 0.82^{\mathrm{Bb}}$ & $4.6 \pm 0.84^{\mathrm{Cb}}$ & $1.5 \pm 0.71^{\mathrm{Dc}}$ \\
\hline & $\mathrm{SC}+0.5 \% \mathrm{ZMEO}$ & $8.9 \pm 0.32^{\mathrm{Aa}}$ & $7.9 \pm 0.74^{\text {Aab }}$ & $5.9 \pm 0.99^{\mathrm{Bab}}$ & $3.2 \pm 0.42^{\mathrm{Cb}}$ \\
\hline & $\mathrm{SC}+1 \% \mathrm{ZMEO}$ & $8.8 \pm 0.42^{\mathrm{Aa}}$ & $8.7 \pm 0.48^{\mathrm{Aa}}$ & $7.6 \pm 0.70^{\mathrm{AB}}$ & $5.9 \pm 0.99^{\mathrm{Ba}}$ \\
\hline & $\mathrm{SC}+1.5 \% \mathrm{ZMEO}$ & $8.7 \pm 0.48^{\mathrm{Aa}}$ & $8.7 \pm 0.48^{\mathrm{Aa}}$ & $7.6 \pm 0.70^{\text {ABaa }}$ & $6.6 \pm 0.70^{\mathrm{Ba}}$ \\
\hline \multirow{4}{*}{ Odor } & SC & $9 \pm 0.00^{\mathrm{Aa}}$ & $6.9 \pm 0.52^{\mathrm{Bab}}$ & $3.1 \pm 0.74^{\mathrm{Cb}}$ & $1.5 \pm 0.71^{\mathrm{Dc}}$ \\
\hline & $\mathrm{SC}+0.5 \% \mathrm{ZMEO}$ & $8.9 \pm 0.32^{\mathrm{Aa}}$ & $7.9 \pm 0.74^{\mathrm{Aa}}$ & $4.6 \pm 0.84^{\mathrm{Bab}}$ & $3.2 \pm 0.42^{\mathrm{Bb}}$ \\
\hline & $\mathrm{SC}+1 \% \mathrm{ZMEO}$ & $8.6 \pm 0.52^{\mathrm{Aa}}$ & $8.2 \pm 0.63^{\mathrm{Aa}}$ & $5.9 \pm 0.99^{\mathrm{Ba}}$ & $6.7 \pm 0.67^{\mathrm{Ba}}$ \\
\hline & $\mathrm{SC}+1.5 \% \mathrm{ZMEO}$ & $6.9 \pm 0.52^{\mathrm{Ab}}$ & $6 \pm 0.82^{\mathrm{Ab}}$ & $5.9 \pm 0.99^{\mathrm{Aa}}$ & $6.1 \pm 0.57^{\mathrm{Aa}}$ \\
\hline \multirow{4}{*}{ Texture } & SC & $8.8 \pm 0.42^{\mathrm{Aa}}$ & $6.6 \pm 0.70^{\mathrm{Bb}}$ & $4.6 \pm 0.84^{\mathrm{Cb}}$ & $3.6 \pm 0.57^{\mathrm{Cc}}$ \\
\hline & $\mathrm{SC}+0.5 \% \mathrm{ZMEO}$ & $8.8 \pm 0.42^{\mathrm{Aa}}$ & $7.6 \pm 0.70^{\mathrm{ABab}}$ & $5.9 \pm 0.99^{\mathrm{BCb}}$ & $4.5 \pm 0.85^{\mathrm{Cbc}}$ \\
\hline & $\mathrm{SC}+1 \% \mathrm{ZMEO}$ & $8.7 \pm 0.48^{\mathrm{Aa}}$ & $8.2 \pm 0.63^{\mathrm{ABa}}$ & $6.6 \pm 0.70^{\mathrm{Bb}}$ & $5.9 \pm 0.99^{\mathrm{Bab}}$ \\
\hline & $\mathrm{SC}+1.5 \% \mathrm{ZMEO}$ & $8.8 \pm 0.42^{\mathrm{Aa}}$ & $8.8 \pm 0.42^{\mathrm{Aa}}$ & $8.2 \pm 0.63^{\mathrm{ABa}}$ & $7.6 \pm 0.70^{\mathrm{Ba}}$ \\
\hline \multirow{4}{*}{ Overall } & $\mathrm{SC}$ & $8.8 \pm 0.42^{\mathrm{Aa}}$ & $6 \pm 0.82^{\mathrm{Bb}}$ & $4.6 \pm 0.84^{\mathrm{Cb}}$ & $3.2 \pm 0.42^{\mathrm{Cb}}$ \\
\hline & $\mathrm{SC}+0.5 \% \mathrm{ZMEO}$ & $8.9 \pm 0.32^{\mathrm{Aa}}$ & $7.6 \pm 0.70^{\mathrm{ABab}}$ & $5.9 \pm 0.99^{\mathrm{BCab}}$ & $4.4 \pm 0.97^{\mathrm{Cab}}$ \\
\hline & $\mathrm{SC}+1 \% \mathrm{ZMEO}$ & $8.8 \pm 0.42^{\mathrm{Aa}}$ & $8.2 \pm 0.63^{\mathrm{ABa}}$ & $6.4 \pm 0.70^{\mathrm{Ca}}$ & $5.9 \pm 0.99^{\mathrm{Ca}}$ \\
\hline & $\mathrm{SC}+1.5 \% \mathrm{ZMEO}$ & $7.9 \pm 0.74^{\mathrm{Aa}}$ & $7.6 \pm 0.70^{\mathrm{ABab}}$ & $7.6 \pm 0.70^{\mathrm{ABa}}$ & $6.2 \pm 0.63^{\mathrm{Ba}}$ \\
\hline
\end{tabular}

SC, sodium caseinate; ZMEO, Zataria multiflora essential oil. Data represent the mean value of three replicates \pm SD. Means within each row with different uppercase letters are significantly different $(P<0.05)$, and means within each column with different lowercase letters are significantly different $(P<0.05)$.

odor of some specimens could not be evaluated on the 15 th day of storage. Notably, the veal specimens coated with 1.5\% ZMEO achieved the maximum scores for texture and overall acceptability. In line with similar studies, the sensory acceptability was confirmed with scores higher than five $[3,26,41]$. In terms of overall acceptability, the control sample fell below this limit prior to the tenth day of storage (below 5), whereas the samples coated with sodium caseinate/ZMEO (1 and 1.5\%) maintained their overall acceptability until the completion of the 15-day study period. Ojagh et al. [4] and Jouki et al. [3] examined fish fillets and found that biopolymerbased antimicrobial coatings could provide significantly higher overall acceptability scores. Furthermore, Moosavi-Nasab et al. [12] described the beneficial effect of essential oils in terms of the overall quality and product life of fish fillets.

\section{Conclusion}

It can be concluded that packaging films comprised of sodium caseinate and ZMEO are able to extend the product life of veal and preserve its sensory traits by postponing both chemical and microbial alterations. Given the consumer demand for the use of natural alternatives to synthetic additives, we recommend the use of ZMEO-incorporated coatings for the preservation of meat products as they were found to possess considerable activity against both oxidants and microbes during the refrigerated storage of veal. Furthermore, the phenolic degradation of ZMEO was impeded 
by the low temperature $\left(4^{\circ} \mathrm{C}\right)$, meaning that the beneficial activity of ZMEO was sustained during the storage time. Ultimately, we found that while SC enriched with $1.5 \%$ ZMEO provided the maximum inhibition of microbes and highest prevention of chemical alterations, it gave rise to unpleasant sensory traits such as odor and probably taste. Therefore, SC plus $1 \%$ ZMEO is recommended to prolong shelf life of meat without any undesirable effect on sensory properties.

\section{Data Availability}

All data and their analysis are included within the manuscript (tables). Raw data are available from the corresponding author upon request (hlashkari@gmail.com).

\section{Conflicts of Interest}

The authors declare that they have no conflicts of interest.

\section{References}

[1] S. Vaithiyanathan, B. M. Naveena, M. Muthukumar, P. S. Girish, and N. Kondaiah, "Effect of dipping in pomegranate (Punica granatum) fruit juice phenolic solution on the shelf life of chicken meat under refrigerated storage $\left(4^{\circ} \mathrm{C}\right)$," Meat Science, vol. 88, no. 3, pp. 409-414, 2011.

[2] D. Georgantelis, I. Ambrosiadis, P. Katikou, G. Blekas, and S. A. Georgakis, "Effect of rosemary extract, chitosan and $\alpha$-tocopherol on microbiological parameters and lipid oxidation of fresh pork sausages stored at $4^{\circ} \mathrm{C}$," Meat Science, vol. 76, no. 1, pp. 172-181, 2007.

[3] M. Jouki, F. T. Yazdi, S. A. Mortazavi, A. Koocheki, and N. Khazaei, "Effect of quince seed mucilage edible films incorporated with oregano or thyme essential oil on shelf life extension of refrigerated rainbow trout fillets," International Journal of Food Microbiology, vol. 174, pp. 88-97, 2014.

[4] S. M. Ojagh, M. Rezaei, S. H. Razavi, and S. M. H. Hosseini, "Development and evaluation of a novel biodegradable film made from chitosan and cinnamon essential oil with low affinity toward water," Food Chemistry, vol. 122, no. 1, pp. 161-166, 2010.

[5] S. Sayanjali, B. Ghanbarzadeh, and S. Ghiassifar, "Evaluation of antimicrobial and physical properties of edible film based on carboxymethyl cellulose containing potassium sorbate on some mycotoxigenic Aspergillus species in fresh pistachios," LWT-Food Science and Technology, vol. 44, no. 4, pp. 1133-1138, 2011.

[6] M. R. Fazeli, G. Amin, M. M. A. Attari, H. Ashtiani, H. Jamalifar, and N. Samadi, "Antimicrobial activities of Iranian sumac and avishan-e shirazi (Zataria multiflora) against some food-borne bacteria," Food Control, vol. 18, no. 6, pp. 646-649, 2007.

[7] H. H. Gahruie, E. Ziaee, M. H. Eskandari, and S. M. H. Hosseini, "Characterization of basil seed gum-based edible films incorporated with Zataria multiflora essential oil nanoemulsion," Carbohydrate Polymers, vol. 166, pp. 93-103, 2017.

[8] H. Gandomi, A. Misaghi, A. A. Basti et al., "Effect of Zataria multiflora Boiss. essential oil on growth and aflatoxin formation by Aspergillus flavus in culture media and cheese," Food and Chemical Toxicology, vol. 47, no. 10, pp. 2397-2400, 2009.
[9] F. Akrami, A. Rodríguez-Lafuente, K. Bentayeb, D. Pezo, S. R. Ghalebi, and C. Nerín, "Antioxidant and antimicrobial active paper based on Zataria (Zataria multiflora) and two cumin cultivars (Cuminum cyminum)," LWT-Food Science and Technology, vol. 60, no. 2, pp. 929-933, 2015.

[10] S. S. Saei-Dehkordi, H. Tajik, M. Moradi, and F. KhalighiSigaroodi, "Chemical composition of essential oils in Zataria multiflora Boiss. from different parts of Iran and their radical scavenging and antimicrobial activity," Food and Chemical Toxicology, vol. 48, no. 6, pp. 1562-1567, 2010.

[11] M. Moradi, H. Tajik, S. M. Razavi Rohani et al., "Characterization of antioxidant chitosan film incorporated with Zataria multiflora Boiss essential oil and grape seed extract," LWT-Food Science and Technology, vol. 46, no. 2, pp. 477484, 2012.

[12] M. Moosavi-Nasab, E. Shad, E. Ziaee, S. H. A. Yousefabad, M. T. Golmakani, and M. Azizinia, "Biodegradable chitosan coating incorporated with black pepper essential oil for shelf life extension of common carp (Cyprinus carpio) during refrigerated storage," Journal of Food Protection, vol. 79, no. 6, pp. 986-993, 2016.

[13] M. Shahamirian, M. H. Eskandari, M. Niakousari, S. Esteghlal, H. Hashemi Gahruie, and A. Mousavi Khaneghah, "Incorporation of pomegranate rind powder extract and pomegranate juice into frozen burgers: oxidative stability, sensorial and microbiological characteristics," Journal of Food Science and Technology, vol. 56, no. 3, pp. 1174-1183, 2019.

[14] S. M. H. Hosseini, H. Hashemi Gahruie, M. Razmjooie et al., "Effects of novel and conventional thermal treatments on the physicochemical properties of iron-loaded double emulsions," Food Chemistry, vol. 270, pp. 70-77, 2019.

[15] E. Ziaee, M. Razmjooei, E. Shad, and M. H. Eskandari, "Antibacterial mechanisms of Zataria multiflora Boiss. essential oil against Lactobacillus curvatus," $L W T$, vol. 87, pp. 406-412, 2018.

[16] M. Moradi, H. Tajik, S. M. Razavi Rohani, and A. Mahmoudian, "Antioxidant and antimicrobial effects of zein edible film impregnated with Zataria multiflora Boiss. essential oil and monolaurin," LWT-Food Science and Technology, vol. 72, pp. 37-43, 2016.

[17] A. C. P. Vital, "Effect of edible and active coating (with rosemary and oregano essential oils) on beef characteristics and consumer acceptability," PLoS One, vol. 11, Article ID e0160535, 2016.

[18] M. Chaijan, S. Benjakul, W. Visessanguan, and C. Faustman, "Changes of pigments and color in sardine (Sardinella gibbosa) and mackerel (Rastrelliger kanagurta) muscle during iced storage," Food Chemistry, vol. 93, no. 4, pp. 607-617, 2005.

[19] A. E. Goulas and M. G. Kontominas, "Effect of salting and smoking-method on the keeping quality of chub mackerel (Scomber japonicus): biochemical and sensory attributes," Food Chemistry, vol. 93, no. 3, pp. 511-520, 2005.

[20] F. Sharififar, M. H. Moshafi, S. H. Mansouri, M. Khodashenas, and M. Khoshnoodi, "In vitro evaluation of antibacterial and antioxidant activities of the essential oil and methanol extract of endemic Zataria multiflora Boiss," Food Control, vol. 18, no. 7, pp. 800-805, 2007.

[21] E. Chouliara, A. Karatapanis, I. N. Savvaidis, and M. G. Kontominas, "Combined effect of oregano essential oil and modified atmosphere packaging on shelf-life extension of fresh chicken breast meat, stored at $4^{\circ} \mathrm{C}$," Food Microbiology, vol. 24, no. 6, pp. 607-617, 2007. 
[22] B. M. Naveena, A. R. Sen, S. Vaithiyanathan, Y. Babji, and N. Kondaiah, "Comparative efficacy of pomegranate juice, pomegranate rind powder extract and BHT as antioxidants in cooked chicken patties," Meat Science, vol. 80, no. 4, pp. 1304-1308, 2008.

[23] F. Varasteh, K. Arzani, M. Barzegar, and Z. Zamani, "Changes in anthocyanins in arils of chitosan-coated pomegranate (Punica granatum L. cv. Rabbab-e-Neyriz) fruit during cold storage," Food Chemistry, vol. 130, no. 2, pp. 267-272, 2012.

[24] A. Ehsani, M. S. Jasour, M. Hashemi, L. Mehryar, and M. Khodayari, "Zataria multiflora Boiss essential oil and sodium acetate: how they affect shelf life of vacuum-packaged trout burgers," International Journal of Food Science \& Technology, vol. 49, no. 4, pp. 1055-1062, 2014.

[25] B. Bazargani-Gilani, J. Aliakbarlu, and H. Tajik, "Effect of pomegranate juice dipping and chitosan coating enriched with Zataria multiflora Boiss essential oil on the shelf-life of chicken meat during refrigerated storage," Innovative Food Science \& Emerging Technologies, vol. 29, pp. 280-287, 2015.

[26] W. Fan, J. Sun, Y. Chen, J. Qiu, Y. Zhang, and Y. Chi, "Effects of chitosan coating on quality and shelf life of silver carp during frozen storage," Food Chemistry, vol. 115, no. 1, pp. 66-70, 2009.

[27] T. Li, J. Li, W. Hu, and X. Li, "Quality enhancement in refrigerated red drum (Sciaenops ocellatus) fillets using chitosan coatings containing natural preservatives," Food Chemistry, vol. 138, no. 2-3, pp. 821-826, 2013.

[28] V. Giatrakou, A. Ntzimani, and I. N. Savvaidis, "Combined chitosan-thyme treatments with modified atmosphere packaging on a ready-to-cook poultry product," Journal of Food Protection, vol. 73, no. 4, pp. 663-669, 2010.

[29] S. Burt, "Essential oils: their antibacterial properties and potential applications in foods-a review," International Journal of Food Microbiology, vol. 94, no. 3, pp. 223-253, 2004.

[30] L. Frangos, N. Pyrgotou, V. Giatrakou, A. Ntzimani, and I. N. Savvaidis, "Combined effects of salting, oregano oil and vacuum-packaging on the shelf-life of refrigerated trout fillets," Food Microbiology, vol. 27, no. 1, pp. 115-121, 2010.

[31] A. Khorsandi, E. Ziaee, E. Shad, M. Razmjooei, M. H. Eskandari, and M. Aminlari, "Antibacterial effect of essential oils against spoilage bacteria from vacuum-packed cooked cured sausages," Journal of Food Protection, vol. 81, no. 8, pp. 1386-1393, 2018.

[32] R. Di Pasqua, G. Betts, N. Hoskins, M. Edwards, D. Ercolini, and G. Mauriello, "Membrane toxicity of antimicrobial compounds from essential oils," Journal of Agricultural and Food Chemistry, vol. 55, no. 12, pp. 4863-4870, 2007.

[33] R. Di Pasqua, G. Mamone, P. Ferranti, D. Ercolini, and G. Mauriello, "Changes in the proteome of Salmonella enterica serovar Thompson as stress adaptation to sublethal concentrations of thymol," Proteomics, vol. 10, no. 5, pp. 1040-1049, 2010.

[34] A. O. Gill and R. A. Holley, "Disruption of Escherichia coli, Listeria monocytogenes and Lactobacillus sakei cellular membranes by plant oil aromatics," International Journal of Food Microbiology, vol. 108, no. 1, pp. 1-9, 2006.

[35] A. Ultee, M. H. J. Bennik, and R. Moezelaar, "The phenolic hydroxyl group of carvacrol is essential for action against the food-borne pathogen Bacillus cereus," Applied and Environmental Microbiology, vol. 68, no. 4, pp. 1561-1568, 2002.

[36] D. Trombetta, F. Castelli, M. G. Sarpietro et al., "Mechanisms of antibacterial action of three monoterpenes," Antimicrobial Agents and Chemotherapy, vol. 49, no. 6, pp. 2474-2478, 2005.
[37] R. A. Mancini and M. C. Hunt, "Current research in meat color,” Meat Science, vol. 71, no. 1, pp. 100-121, 2005.

[38] D. B. MacDougall, "Changes in the colour and opacity of meat," Food Chemistry, vol. 9, no. 1-2, pp. 75-88, 1982.

[39] O. P. Soladoye, M. L. Juárez, J. L. Aalhus, P. Shand, and M. Estévez, "Protein oxidation in processed meat: mechanisms and potential implications on human health," Comprehensive Reviews in Food Science and Food Safety, vol. 14, no. 2, pp. 106-122, 2015.

[40] J. M. Lorenzo, R. Batlle, and M. Gómez, "Extension of the shelf-life of foal meat with two antioxidant active packaging systems," LWT-Food Science and Technology, vol. 59, no. 1, pp. 181-188, 2014.

[41] S. F. Mexis, E. Chouliara, and M. G. Kontominas, "Combined effect of an oxygen absorber and oregano essential oil on shelf life extension of rainbow trout fillets stored at $4^{\circ} \mathrm{C}$," Food Microbiology, vol. 26, no. 6, pp. 598-605, 2009. 